\title{
Foals Developmental Orthopedic Disease Associated with Metabolic and Biometric Characterization of Pregnant Overweight Crioulo Mares
}

\author{
Anibal Janczak Torres', Carlos Eduardo Wayne Nogueira², Alice Correa², Carolina Litchina Brasil'2, \\ Ilusca Sampaio Finger ${ }^{3}$, Josiane Feijó ${ }^{2}$, Mariana Andrade Mousquer ${ }^{2}$, Grasiela De Bastiani ${ }^{4}$ \& Adriana Pires Neves ${ }^{5}$
}

\begin{abstract}
Background: Musculoskeletal changes in growing foals can be linked to metabolic disorders which affect the cartilage metabolism associated of obesity during the late gestation of the mares, negatively affecting the athletic performance of the otherwise prospective foals. High basal insulin levels can be associated with increased weight and obesity of the mares, altering the supply of the glucose to the fetus and the production of IGF-1, which plays an important role in the endochondral cartilage metabolism. The present study aims to describe the association of metabolic and biometric alterations in overweight Criollo mares with IGF-1 levels and the presence of articular and physeal lesions in their foals.

Materials, Methods \& Results: A prospective and observational cohort study was conducted using the foals and the overweight mares at field conditions. Twenty-eight foals and their overweight mothers were utilized. The foals' biometric and metabolic features as weight and height; glucose, total cholesterol, cholesterol HDL, triglycerides, basal insulin, leptin, glucose, total T4 and IGF-1 were analyzed, from the birth until the weaning period around sixth month of life of it. All the foals, at the weaning period, were submitted to the radiograph examination of the tarsal joints and the metacarpal-phalangeal joints to evaluate signs of lesions and the possible distal metacarpal physeal changes, respectively. The mares' biometric and metabolic features as weight, height and fat tail-head deposition; basal insulin, leptin, glucose, total cholesterol, cholesterol HDL and triglycerides were analyzed at the final period of gestation. The basal insulin levels of the foals at the second, fourth and sixth month of life were $9.87 \pm 1.82 \mu \mathrm{UI} / \mathrm{mL}, 9.13 \pm 1.94 \mu \mathrm{UI} / \mathrm{mL}, 9.39 \pm 2.54 \mu \mathrm{UI} / \mathrm{mL}$. The IGF-1 levels of the foals at the second, third, fourth, fifth and sixth month of life were $290.27 \pm 79.72 \mathrm{ng} / \mathrm{mL} ; 180.77 \pm 66.22 \mathrm{ng} /$ $\mathrm{mL} ; 151.79 \pm 46.64 \mathrm{ng} / \mathrm{mL} ; 110.81 \pm 33.13 \mathrm{ng} / \mathrm{mL}$ and $89.59 \pm 14.00 \mathrm{ng} / \mathrm{mL}$. At weaning, foals presented osteoarthritis of the distal tarsus joints $(92.85 \%)$ and physitis of the distal metacarpal epiphyseal plate (50\%). The weight and the basal insulin levels of the mares at the last three months of gestation were $501.80 \pm 6.4 \mathrm{~kg}, 511.76 \pm 8.0 \mathrm{~kg}, 533.23 \pm 8.2 \mathrm{~kg}$ and $11.7 \pm 2.1 \mu \mathrm{UI} / \mathrm{mL}, 9.8 \pm 1.1 \mu \mathrm{UI} / \mathrm{mL}, 13.7 \pm 1.6 \mu \mathrm{UI} / \mathrm{mL}$, respectively.

Discussion: In the present study, from the second to the sixth month of the period life, the foals showed IGF-1 levels of 290 to $89 \mathrm{ng} / \mathrm{mL}$, and demonstrated, at 6-month-old, a prevalence of $92.85 \%$ of distal tarsus lesions and $50 \%$ of physitis of the distal metacarpal epiphyseal plate. In association, the overweight mares showed an increase of the insulin basal levels when nearing parturition. The occurrence of physitis in 50\% of the 6-month-old foals in the present study demonstrate that the metabolic changes are involved in this process and the IGF-1 levels were observed to be lower than in healthy foals of other breeds. The lower IGF-1 levels during the developmental period of the foals are associated with a decrease of bone density and mass, musculoskeletal atrophy and osteoarthritis. In the present study, the decreasing curve of IGF-1 levels $(P<0.05)$ of the foals, from the second to sixth month of life, is similar to others researches with foals from other breeds from 0 to 7 months of life. In previous researches with Crioulo horses, it was observed that foals aged less than 18 months had up to $100 \%$ of prevalence of articular tarsus lesions. This suggest that the tarsus lesions observed in $92.85 \%$ of the 6-month-old foals in the present study, could not heal and that lesions should remain in the foals to adulthood.
\end{abstract}

Keywords: overweight mares, late gestation, foals, musculoskeletal changes, IGF-1 levels, insulin levels. 


\section{INTRODUCTION}

Articular and physeal lesions in young horses can collectively be referred to Developmental Orthopedic Diseases (DOD) and are classified either as juvenile osteoarthritis or physeal dysplasia, respectively [28]. Such changes can be related to overfeeding and obesity during the late gestation, which can lead to metabolic changes in both, the mare and the foal, negatively affecting the athletic performance of the otherwise prospective foals [14,20,22,32,37].

High basal insulin levels associated with increased weight and obesity of the mares can lead to the decreased pancreatic $\beta$ cell sensitivity, altering the supply of the glucose to the fetus [14,22,32,37]. This metabolic mechanism can alter the insulin and the glucose dynamic during the first few months of the foal's life, which, as a consequence, alters the production of the IGF-1 (insulin like growth factor 1 ), which plays an important role in the endochondral cartilage metabolism. IGF-1, for this reason, can be considered an important biomarker for articular changes in young horses $[6,7,25,29]$. The high body condition score (BCS), together with the accumulated body fat, are factors related to tarsus lesions in up to $100 \%$ of 18 -months-old Crioulo foals [5]. The distal tarsal lesions were also found in $40.80 \%$ of adult Crioulo horses presenting lameness during the training period, representing $76.47 \%$ of the posterior limb pathologies and demonstrating the seriousness and the prevalence of this disease in these athletic horses [3].

The present study aims do describe the association of metabolic and biometric alterations in overweight Criollo mares with IGF-1 levels and the presence of articular and physeal lesions in their foals.

\section{MATERIALS AND METHODS}

\section{Animals}

Twenty-eight Crioulo foals and their respective dams, with an average age of 6.5 (4-9) years were studied, from late gestation until six months of age of the foals, maintained under field conditions. All the animals were privately owned and located at a farm in Rio Grande do Sul State, city of Capão do Leão, geographic coordinates S $31,7313^{\circ}$ e W 52,5652 ${ }^{\circ}$. The experiment was held between June of 2015 and
June of 2016. The pregnant mares and their foals were kept on 50 hectares of native pasture, improved with cultivated ryegrass pasture (Lollium multiflorum), without carbohydrate supplementation. All mares had their body condition score (BCS) determined by a singular trained veterinarian at the beginning of the experiment, and those with a $\mathrm{BCS} \geq 7$ were classified as overweight (BCS 1 is so skin and BCS 10 is so fat [23]).

\section{Foal evaluations}

The sex of the foals was not differentiated in this research work. The foals were evaluated at $12 \mathrm{~h}$ after birth, then monthly for the first 6 months of life, recording the following biometric, clinic and metabolic measurements: height (m), using a standardized measuring stick; weight (kg), using a scale; and blood levels of triglycerides ${ }^{1}(\mathrm{mg} / \mathrm{dL})$, cholesterol $\mathrm{HDL}^{1}(\mathrm{mg} / \mathrm{dL})$ and total cholesterol ${ }^{1}(\mathrm{mg} / \mathrm{dL})$. At 2, 4 and 6 months of life of the foals, blood levels of glucose ${ }^{1}(\mathrm{mg} / \mathrm{dL})$, basal insulin ${ }^{2}(\mu \mathrm{UI} / \mathrm{mL})$, total thyroxin (T4)2 ( $\left.\mu \mathrm{g} / \mathrm{dL}\right)$ and leptin $^{3}(\mathrm{ng} / \mathrm{mL})$ were evaluated. At 2, 3, 4, 5 and 6 months of life of the foals, IGF-1 blood levels (insulin like growth factor- 1$)^{4}[\mathrm{ng} / \mathrm{mL}]$ were determined. The percentage $(\%)$ of the relation between the foals' birthweight $(\mathrm{kg})$ and the mares' weight $(\mathrm{kg})$ prior to parturition was determined through simple division of the foals' birthweight/ mares' weight at the tenth month of gestation $\mathrm{x} 100$, according to the method previous described [37].

The locomotor system was evaluated by a clinician using the AAEP grading system [1] for possible subjective analysis of lameness, during all moments of the experiment.

At foals' sixth month of life, during the weaning period, radiographic evaluations were performed. In order to identify possible articular changes at the distal tarsal joints, radiographic imaging of the both pelvic members were obtained; and to identify possible distal metacarpal physeal changes, radiographic imaging of the metacarpal-phalangeal joints of both thoracic members was obtained. For each joint, four standard radiographic projections were performed with the RX machine (DR RX EcoRay) 5 [10]: lateromedial, dorsoplantar, dorsolateral - plantaromedial oblique and dorsomedial - plantarolateral oblique. Score grade lesions were classified [33], and are described in Table 1. 
Table 1. Score grade radiographic lesions according to one Grading system*.

\begin{tabular}{cc}
\hline Grade & Description \\
\hline 1 & Without or slight radiographic changes \\
2 & Mild abnormal radiographic changes \\
3 & Moderate abnormal radiographic changes \\
4 & Severe abnormal radiographic changes \\
\hline
\end{tabular}

*Robert, Valette e Denoix [33].

\section{Gestational evaluation}

The mares were evaluated during the late gestational period, at 240, 270 and 300 days of pregnancy. All mares conceived from October 2014 until December 2014, and the gestational time of each mare was determined at the moment of the delivery. At 240 days of gestation the height and length of each mare was measured using a standardized measuring stick and a measuring tape, and found to be on average 1.388 \pm 0.005 meters and $1.775 \pm 0.012$ meters, respectively. At 240, 270 and 300 days of gestation, measurements of weight $(\mathrm{kg})$ were recorded through the use of a scale; and subcutaneous fat depths at the tail-head ( $\mathrm{mm}$ ) were obtained with the aid of an ultrasound machine (Mindray $\left.^{\circledR} 2200\right)^{6}$ and linear probe 5-10 MHz [19]. Also, at these moments, blood levels of triglycerides $1(\mathrm{mg} / \mathrm{dL})$, cholesterol $\mathrm{HDL}^{1}(\mathrm{mg} / \mathrm{dL})$ and total cholesterol ${ }^{1}(\mathrm{mg} /$ $\mathrm{dL})$, glucose $\mathrm{g}^{1}(\mathrm{mg} / \mathrm{dL})$, basal insulin ${ }^{2}(\mathrm{mg} / \mathrm{dL})$, leptin ${ }^{3}$ $(\mathrm{ng} / \mathrm{mL})$, were analyzed. Lameness was not observed in any of the mares during the experimental period.

\section{Biochemistry and endocrinal laboratorial analysis}

For laboratorial analyses, $15 \mathrm{~mL}$ of blood samples were taken through the external jugular vein puncture from the mares and the foals using the sterile tube BDVacutainer ${ }^{\circledR 7}$ system, with and without anticoagulant tubes. Samples were centrifuged at $800 \mathrm{~g}$ during $10 \mathrm{~min}$ to separate serum, plasma and supernatant fraction and were stored frozen at $-20^{\circ} \mathrm{C}$. For the IGF-1 analysis, the serum samples were stored frozen at $-70^{\circ} \mathrm{C}$. The samples were processed at the Biochemistry Laboratory of the Department of Large Animal Clinics of UFPel.

\section{Statistical analysis and correlations}

A descriptive statistical analysis and Pearson's test for the data correlation was performed using the commercial program Statistix $10^{8}$. The normality of the data was verified using the Shapiro-
Wilk test and the data considered as not normal was transformed. All the data was presented as averages \pm standard deviation. The analysis interval of variation was about $5 \%$ and the test coefficients did not exceed $10 \%$. The correlations between the data of the mares and the foals were performed using the Pearson's test and the statistical significance was determined using the Fisher's test. The statistical correlations between the data were observed for the following: mares' gestational weight (during the final trimester) and foals' weight during the first six months of life; time to parturition, and foals weight and height at birth; insulin levels of mares' during late gestation (final trimester), with insulin and IGF-1 levels of foals from 2 to 6 months of life; weight and subcutaneous fat depths at the tail-head of mares during the late gestation (final trimester), with leptin levels of the same mares during that same time

\section{RESULTS}

\section{Foals}

The metabolic and the biometric features observed in foals, from birth until 6 months of life, are shown in Tables 2 and 3 (different letters between moments means $P<0.05$ ). The IGF-1 levels of the foals $(\mathrm{ng} / \mathrm{mL}$ ) obtained monthly, from second to sixth months of life were found to be $290.27 \pm 79.72^{\mathrm{a}} ; 180.77$ $\pm 66.22^{\mathrm{ab}} ; 151.79 \pm 46.64^{\mathrm{b}} ; 110.81 \pm 33.13^{\mathrm{c}}$ and 89.59 $\pm 14.00^{\mathrm{cd}}$, respectively, and are described in Graphic 1 (different letters between moments means $P<0.05$ ). Lameness was not observed in any of the foals during the experimental period.

The radiographic exams were performed during the weaning period, when the foals were around 6 months old, and are described in Table 4.

The foals' birthweight was found to be $7.76 \%$ of the mares' weight at the last month of gestation (foals' average birthweight was $41.41 \pm 1.35 \mathrm{~kg}$ and mares' average weight at tenth month of gestation was $533.23 \pm 8.2 \mathrm{~kg}$ ). The birth month, during the foaling period, did not have an influence on weight, height and radiographic changes of the foals.

The correlation analysis data of the weight of the mares at tenth month of gestation with the foals' birthweight was $\mathrm{R}=0.45$ and $P=0.003$; the time to parturition with weight and height of the foals at birth was $\mathrm{R}=0.40$ and $P=0.03$. There was no correlation $(P>0.05)$ of the insulin levels of the mares at eighth, 
ninth and tenth month of gestation, with the insulin and the IGF-1 levels of the foals at second, third, fourth, fifth and sixth month of life. The weight and the subcutaneous fat depths at the tail-head of the mares had no correlation $(P>0.05)$ with the leptin levels of it at eighth, ninth and tenth month of gestation.
Mares

The average gestation time of the 28 mares was found to be $332.78 \pm 2.18$ days. The results of the metabolic and the biometric features at 240, 270 and 300 days of gestation are described in Table 5 (different letters between moments means $P<0.05$ ).

Table 2. Results of metabolic features of foals at the second, fourth and sixth month of life.

\begin{tabular}{cccc}
\hline Result/Moment & 2 months & 4 months & 6 months \\
\hline Glucose $(\mathrm{mg} / \mathrm{dL})$ & $122.65^{\mathrm{a}} \pm 4.05$ & $110.85^{\mathrm{ab}} \pm 3.49$ & $105.46^{\mathrm{b}} \pm 3.42$ \\
Insulin $(\mu \mathrm{UI} / \mathrm{mL})$ & $9.87 \pm 1.82$ & $9.13 \pm 1.94$ & $9.39 \pm 2.54$ \\
Total T4 $(\mu \mathrm{g} / \mathrm{dL})$ & $3.2 \pm 0.32$ & $2.64 \pm 0.41$ & $2.44 \pm 0.42$ \\
Leptin $(\mathrm{ng} / \mathrm{mL})$ & $1.60 \pm 0.02$ & $1.59 \pm 0.021$ & $1.54 \pm 0.019$ \\
\hline
\end{tabular}

Different letters between moments means $P<0.05$.

Table 3. Radiographic changes according to one Grading system* observed in foals at weaning period.

\begin{tabular}{ccc}
\hline Grade & Metacarpal physitis & Distal tarsus osteoarthritis \\
\hline Grade 1 & $50 \%(14 / 28)$ & $7.14 \%(2 / 28)$ \\
Grade 2 & $39.28 \%(11 / 28)$ & $50 \%(14 / 28)$ \\
Grade 3 & $0 \%(0 / 28)$ & $21.42 \%(6 / 28)$ \\
Grade 4 & $10.71 \%(3 / 28)$ & $21.42 \%(6 / 28)$ \\
\hline Total & $50 \%(14 / 28)$ & $92.85 \%(26 / 28)$ \\
\hline
\end{tabular}

*Robert, Valette e Denoix [33].

Table 4. Results of metabolic and biometric features at 240, 270 and 300 days of gestation of the mares.

\begin{tabular}{cccc}
\hline Result/Moment & 240 days & 270 days & 300 days \\
\hline Weight $(\mathrm{Kg})$ & $501.80 \pm 6.4^{\mathrm{a}}$ & $511.76 \pm 8.0^{\mathrm{b}}$ & $533.23 \pm 8.2^{\mathrm{c}}$ \\
Fat at tail-head $(\mathrm{mm})$ & $19.2 \pm 1.35^{\mathrm{a}}$ & $22.6 \pm 1.08^{\mathrm{bc}}$ & $24.7 \pm 0.91^{\mathrm{c}}$ \\
Glucose $(\mathrm{mg} / \mathrm{dL})$ & $86.5 \pm 1.61$ & $86.6 \pm 1.45$ & $88.6 \pm 1.3$ \\
Insulin $(\mu \mathrm{UI} / \mathrm{mL})$ & $11.7 \pm 2.1^{\mathrm{ab}}$ & $9.8 \pm 1.1^{\mathrm{a}}$ & $13.7 \pm 1.6^{\mathrm{b}}$ \\
Leptin $(\mathrm{ng} / \mathrm{mL})$ & $1.63 \pm 0.049^{\mathrm{a}}$ & $1.65 \pm 0.044^{\mathrm{a}}$ & $1.53 \pm 0.035^{\mathrm{b}}$ \\
Cholesterol HDL $(\mathrm{mg} / \mathrm{dL})$ & $55.31 \pm 1.51$ & $56.49 \pm 1.14$ & $56.87 \pm 1.29$ \\
Total Cholesterol $(\mathrm{mg} / \mathrm{dL})$ & $71.51 \pm 3.62$ & $72.46 \pm 4.40$ & $72.45 \pm 4.30$ \\
Triglycerides $(\mathrm{mg} / \mathrm{dL})$ & $24.88 \pm 1.81$ & $27.34 \pm 2.27$ & $28.41 \pm 2.27$ \\
\hline
\end{tabular}

Different letters between moments means $P<0.05$.

Table 5. Results of metabolic and biometric features of foals measured monthly from the second to sixth month of life.

\begin{tabular}{|c|c|c|c|c|c|c|c|}
\hline Result/Moment & At birth & 1 month & 2 months & 3 months & 4 months & 5 months & 6 months \\
\hline Weight (kg) & $41.41 \pm 1.35$ & $80.62 \pm 2.68$ & $109.09 \pm 4.11$ & $131.61 \pm 5.13$ & $160.95 \pm 5.75$ & $183.60 \pm 8.6$ & $206.08 \pm 11.83$ \\
\hline Height (m) & $0.94 \pm 0.14$ & $1.04 \pm 0.08$ & $1.09 \pm 0.10$ & $1.14 \pm 0.10$ & $1.18 \pm 0.16$ & $1.18 \pm 0.13$ & $1.22 \pm 0.16$ \\
\hline Cholesterol HDL (mg/dL) & $62.68 \pm 1.93$ & $66.68 \pm 1.77$ & $65.17 \pm 1.92$ & $64.36 \pm 1.33$ & $66.33 \pm 1.51$ & $62.69 \pm 1.92$ & $65.80 \pm 1.82$ \\
\hline Total Cholesterol (mg/dL) & $126.96 \pm 4.92^{\mathrm{ab}}$ & $121.48 \pm 4.25^{\mathrm{ab}}$ & $125.13 \pm 4.68^{\mathrm{ab}}$ & $131.47 \pm 4.14^{\mathrm{a}}$ & $123.84 \pm 5.53^{\mathrm{ab}}$ & $119.30 \pm 5.56^{\mathrm{ab}}$ & $124 \pm 4.57^{b}$ \\
\hline Triglycerides (mg/dL) & $50.92^{\mathrm{a}} \pm 6.22^{\mathrm{a}}$ & $39.62 \pm 2.17^{\mathrm{ab}}$ & $40.37 \pm 3.45^{\mathrm{ab}}$ & $42.73 \pm 2.97^{b}$ & $37.95 \pm 3.15^{\mathrm{ab}}$ & $37.53 \pm 3.50^{\mathrm{ab}}$ & $37.66 \pm 2.53^{\mathrm{ab}}$ \\
\hline
\end{tabular}

Different letters between moments means $P<0.05)$. 


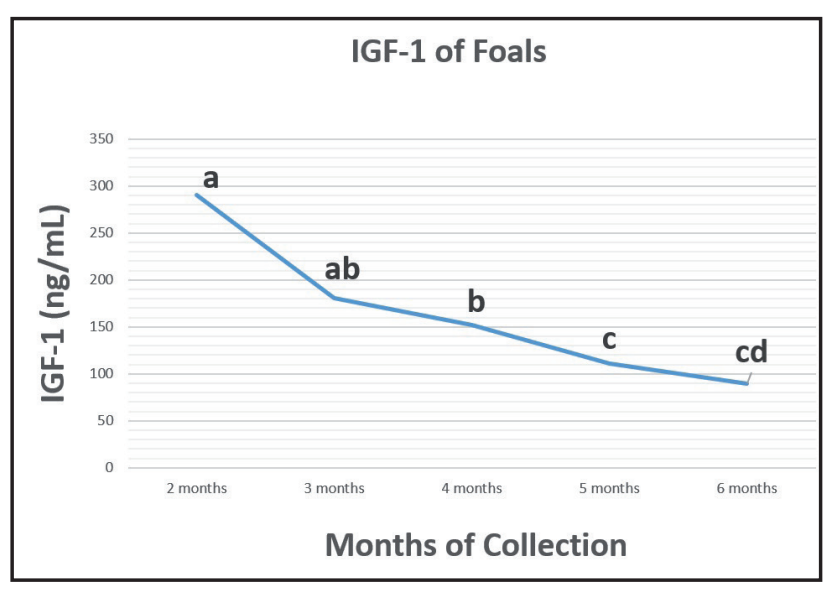

Graphic 1. Monthly IGF-1 levels (ng/mL) of the foals from the second to sixth month of life (different letters between moments means $P<0.05$ ).

\section{DISCUSSION}

In the present study, from second to sixth month of the period life, the foals showed decreasing IGF-1 levels of 290 to $89 \mathrm{ng} / \mathrm{mL}$, and demonstrated, at 6-month-old, a prevalence of $92.85 \%$ of distal tarsus lesions and $50 \%$ of physitis of the distal metacarpal epiphyseal plate. These IGF-1 levels are similar to those found in Lusitano foals also with DOD, with 159 to $114 \mathrm{ng} / \mathrm{mL}$ from the second to sixth month of life, while healthy foals at the same age were observed to have IGF-1 levels of 343 to $219 \mathrm{ng} / \mathrm{mL}$ [6]. In Ardenner foals with radiographic articular changes was observed lower IGF-1 levels compared to healthy foals $(P<0.05)$ [25], similar results to that found in the present study.

The occurrence of physitis in 50\% of the 6-month-old foals, in the present study, demonstrate that metabolic changes are involved in this process and the IGF-1 levels were observed to be lower than in normal foals of other breeds. It was shown a possible involvement in a deficient chondrocyte proliferation in this process $[6,16]$. This is important because the physeal plate of the distal metacarpus calcifies between 6 and 8 months of life of the foals [10], and in this process, as in the joints, chondrocytes proliferate, undergo hypertrophy and then occurs the apoptosis. These events are regulated by some systemic factors like IGF-1, insulin and thyroid hormones. In the present study, the decreasing curve of the IGF-1 levels of the foals $(P<0.05)$, from 2 to 6 month of life, is similar to others researches studying foals from other breeds from 0 to 7 months of life $[6,16]$.

IGF-1 is important in promoting differentiation and hypertrophy of the chondrocyte during the endochondral and the epiphyseal ossification process [29], and also in the healing of articular lesions which occurs during the foals' first months of life [15]. Lower IGF1 levels during the developmental period of foals are associated with a decrease of bone density and mass, musculoskeletal atrophy and osteoarthritis $[9,16,25]$. In french saddle (Selle Français) foals was also described a transient osteochondrosis, which showed an improvement of this disease from 6 to 18 months of life, both in the foals from "obese" and "non-obese" mares [34]. Since it is understood that IGF-1 is involved in the cartilage repair in osteoarthritic horses, it is believed that the lower levels of IGF-1 are related with non-healing of the articular lesions during the puberty period (around 7-8 months of the foals) $[15,17]$. In two previous researches with Crioulo horses, it was observed that the foals aged less than 26 months had a $79.2 \%$ [18] and $100 \%$ [5], of prevalence of articular tarsus lesions. These suggests that the tarsus lesions observed in $92.85 \%$ of the 6-month-old foals in the present study could not heal and that lesions should remain in the foals to adulthood.

In similar research it was related osteoarticular lesions observed in 21-month-old foals with their dams' food supplemented during the gestational period [22]. Pregnant mares in the present study were not fed with carbohydrate supplements during gestation, however, these mares were all classified as overweight following the body condition score (BCS) [23], even though, it was kept only on pasture. Previously study observed that pasture, during the growth period of the grass when the content is rich in soluble carbohydrates, can cause weight gain in the foals and is related to increased developmental growth, articular cartilage degeneration and early calcification of the physeal plate without it being ideally prepared for the ossification, predisposing it to physitis [8]. It was showed previously a relationship between the ingestion of large amounts of fructan, presented in the grasses, with obesity, increased insulin levels and metabolic disease in horses [24,38]. In the present study, increased weight gains and fat accumulated of the tail-head of the mares during late gestation $(P<0.05)$ [from 240 to 300 days of gestation], together with the increase of the insulin basal levels $(P<0.05)$ (from 270 to 300 days of gestation), coincides with the greatest period of growth of the ryegrass (Lolium multiflorum) presented on the pasture. It is hypothesized that the fructan could be present in this type of cultivated grass, and since it is a non-structural rapidly 
fermentable carbohydrate composed of simple sugars, could stimulate the pancreas to secrete large amounts of insulin into the blood flow [24].

The thyroid hormones and the insulin are involved in the process of proliferation and hypertrophy of the chondrocytes during the articular and physeal endochondral ossification. In this process, the insulin removes the thyroid hormones from the blood flow, therefore the foals with hyperinsulinemia have this mechanism compromised, leading to alterations in the endochondral ossification process $[6,7,25,29]$. In the present study, there was no hyperinsulinemia, neither hyperglycemia found in any of the mares nor the foals, however, an increase of the insulin levels from 270 to 300 days of gestation in the mares $(P<0.05)$ was observed. Foals maintained the insulin levels at the second, fourth and sixth months of life $(P>0.05)$. The decrease of the blood glucose levels in these foals from the second to sixth month of life can be explained through the decrease ingestion of mares' milk, and consequently, a decrease ingestion of the lactose when feeding on pasture [9]. Total T4 levels of the foals of this study did not differ from the second, fourth and sixth months of life $(P>0.05)$ and were found to be within physiologic values. In agreement with this, in weaned Thoroughbred foals it was not found significant difference in total T4 values between with and without articular lesions, showing no correlation between $\mathrm{T} 4$ values and the presence of osteochondrosis [34].

Previous studies with obese Thoroughbred and french saddle (Selle Français) mares demonstrated that the increased insulin levels during the final trimester of gestation $(P<0.05)$ were associated with the low insulin levels in nursing foals which developed osteoarthritis $[9,34]$. Contrary to this, in our study, no significant correlation between the mares and the foals' insulin levels was found $(P>0.05)$.

The mechanism of the insulin is not well understood in regards to the fetal influence, and as a consequence, is not well understood in the first few months of the foals' life, but some authors concluded that the insulin levels were related to the onset of the osteoarticular lesions in young horses $[9,34]$. The increase of the blood glucose levels during late gestation cause an increase of the insulin resistance in mares, and could affect the fetal metabolism [14,20,32,34,37]. That being said, this mechanism was not observed in the present study, since the glycemic levels were maintained during the mare's late gestation.
Hyperleptinemia did not occur in any of the Crioulo mares in the present study, but a decrease of the leptin levels $(P<0.05)$ was observed from the ninth to the tenth month of gestation. In contrast, others authors when studying Crioulo mares, found a significantly positive correlation between the body condition score (BCS) and the increase of the leptin levels $(P<0.05)$ in "obese" mares when nearing parturition, and the decrease of the leptin levels in the "non-obese" group during the same time period $(P<0.05)$ [27]. Horses with higher body fat deposition present higher leptin levels [11]. However, the leptin levels in the present study were not found to be related with the increase body weight or the accumulate of the subcutaneous fat at the tail-head of the mares, agreeing with what was found in obese Thoroughbred mares [2,37]. The decreasing leptin curve observed in others researches in the "non-obese" group of Crioulo mares at the late gestation [27] is similar to the leptin curve found in the present study of overweight mares.

The time from the conception to the parturition of the overweight mares in this study was found to be $332.78 \pm 2.18$ days. In other study with Thoroughbred mares overfed with carbohydrates in late gestation it was found an average gestational duration of $346 \pm 2$ days [20], a value above what was witnessed in the current study. Studying Crioulo mares, others authors found the mares gestational average duration of 335.6 \pm 10.5 days [40], a value also slightly higher than that of the present study. Wellfed mares generally seem to present shorter time to parturition than mares with nutritional restrictions or in poor pasture availability during late gestation [36]. When the mares have a good body condition score (BCS), this generally means that the foals will be born into a nutritionally favorable environment, and for this reason, a shorter gestational time can be expected. When the nutritional conditions are poor, or not available to the mare for an extended period of time, gestational days can be 4 to 10 days longer since the fetus requires more time to develop and mature in the preparation for the unfavorable nutritional environment [36]. In the present study were observed that the overweight mares had lower days of gestation than that found in researches of others breeds, and even in the previous research of the Crioulo breed [20,40], which could be explained by the excellent nutritional conditions that the overweight mares were kept in. 
The positive correlation between the time to parturition and the foals' birthweight is in contrast to what other study found [4], whereby the Thoroughbred mares with longer gestational durations were observed giving birth to lighter foals. The positive correlation between mares' weight at the tenth month of gestation with the foals' birthweight $(P<0.05)$, agrees with previous studies which observed heavier foals born from Thoroughbred mares with higher body condition score [4], and greater body weight [37], however, other study did not notice this relationship [30]. In other mammalian species, the increased birthweight has been associated with obesity, osteoarthritis and metabolic disorders [26], which has been observed in the present study, where the overweight mares gave birth to foals with $92.85 \%$ of prevalence of articular changes at 6 months of life.

\section{CONCLUSION}

The overweight mares showed an increase of the insulin basal levels when nearing parturition, and gave birth to foals which $92.85 \%$ demonstrated distal tarsus osteoarthritis at the age of 6 months. These findings were associated with low IGF-1 levels of the Crioulo foals.

\author{
MANUFACTURERS \\ ${ }^{1}$ Labtest Diagnóstica S/A. Lagoa Santa, MG, Brazil. \\ ${ }^{2}$ Beckman Coulter Inc. Brea, CA, USA. \\ ${ }^{3}$ Merck KGaA. Kansas, MO, USA. \\ ${ }^{4}$ Cusabio Lab Research. Houston, TX, USA. \\ ${ }^{5}$ EcoRay. Seoul, Gyeonggi, Korea. \\ ${ }^{6}$ Shenzhen Mindray Bio-Medical Electronics Company Ltd. Shenzhen, \\ GD, China. \\ ${ }^{7}$ Becton, Dickinson and Company. Franklin Lakes, NJ, USA. \\ ${ }^{8}$ Analytical Software. Tallahassee, FL, USA.
}

Funding. CAPES and ABCCC provided financial support for this research.

Ethical Approval. This study has approval from Federal University of Rio Grande do Sul by the Ethical Committee number CEEA 8245.

Declaration of interest. The authors report no conflict of interest. The authors alone are responsible for the content and writing of paper.

\section{REFERENCES}

1 AAEP. LAMENESS EXAMS: Evaluating the Lame Horse. Available at: <https://aaep.org/horsehealth/lameness-examsevaluating-lame-horse>. [Accessed online in January 2019].

2 Abo El-Maaty A.M., Mohamed A.H., Abu-Aita N.A. \& Morgan H.M. 2017. Markers for Predicting Overweight or Obesity of Broodmares. Journal of Equine Veterinary Science. 56: 9-18.

3 Abreu H. C., De La Corte F.D., Brass K.E., Pompermayer E., Da Luz T.R.R. \& Gasperi D. 2011. Claudicação em cavalos Crioulos atletas. Ciência Rural. 41(12): 2114-2119.

4 Aiex L.F. 2008. Birth Weight and growth of New Zealand Thoroughbred foals. 117p. Palmerston North, MWT. Thesis (Master of Veterinary Studies), Massey University.

5 Amaral L.A., Marchiori M., Moraes B.S., Finger I., dos Santos R.S. \& Nogueira C.E.W. 2017. Relação entre adiposidade, perfil energético, proteínas inflamatórias e lesões osteoarticulares em equinos jovens sobre diferentes sistemas de criação. Pesquisa Veterinária Brasileira. 37(2): 115-120.

6 Baccarin R.Y.A., Pereira M.A., Roncati N.V., Furtado P.V., Oliveira C.A. \& Hagen S.C.F. 2011. Identificação dos níveis séricos do fator de crescimento tipo insulina $1 \mathrm{em}$ potros com osteocondrose. Pesquisa Veterinária Brasileira. 31(8): 677-682.

7 Böhme K., Conscience-Egli M., Tschan T., Winterhalter K.H. \& Bruckner P. 1992. Induction of proliferation or hypertrophy of chondrocytes in serum-free culture: the role of insulin-like growth factor-I, insulin, or thyroxine. The Journal of Cell Biology. 116(4): 1035-1042.

8 Bramlage L.R. 2011. Physitis in the horse. Equine Veterinary Education. 23(11): 548-552.

9 Bryden W.L., Foote C.E., Cawdell-Smith A.J. \& Anderson S.T. 2013. Insulin dynamics during equine pregnancy - Possible relationship to osteochondrosis in foals. Canberra: Rural Industries Research and Development Corporation, 35p.

10 Butler J.A., Colles C.M., Dyson S.J., Kold S.E. \& Poulos K.W. 2011. Clinical Radiology of the Horse. 3rd edn. London: Blackwell Science Ltd, pp.220-225.

11 Cavinder Clay A., Vogelsang M.M., Gibbs P.G., Forrest D.W. \& Schmitz D.G. 2007. Endocrine Profile Comparisons of Fat Versus Moderately Conditioned Mares Following Parturition. Journal of Equine Veterinary Science. 27(2): $72-79$. 
12 De Bastiani G., De La Corte F.D., Brass K.E., Kommers G.D. \& Denoix J.M. 2014. Association of Ultrasound and Anatomopathologic Findings of Equine Metacarpophalangeal Lesions. Journal of Equine Veterinary Science. 34(10): 1218-1225.

13 De Bastiani G., De La Corte F.D., Brass K.E., Cantarelli C., Dau S., Kommers G.D., Da Silva T.M. \& Azevedo M.S. 2018. Histochemistry of Equine Damaged Tendons, Ligaments and Articular Cartilage. Acta Scientiae Veterinariae. 46: 1-8.

14 Dobbs T.N. 2013. Glucose and insulin dynamics in mares and their foals. 232p. Brisbane, QLD. PhD Thesis. School of Agriculture and Food Sciences, The University of Queensland.

15 Fortier L.A, Balkman C.E, Sandell L.J. \& Nixon A.J. 2001. Insulin-like growth factor-I gene expression patterns during spontaneous repair of acute articular cartilage injury. Journal of Orthopedic Research. 19(4): 720-728.

16 Fortier L.A., Kornatowski M.A., Mohammed H.O., Jordan M.T., O’Cain L.C. \& Stevens W.B. 2005. Age-related changes in serum insulin-like growth factor-I, insulin-like growth factor-I binding protein-3 and articular cartilage structure in Thoroughbred horses. Equine Veterinary Journal. 37(1): 37-42.

17 Frisbie D.D., Ghivizzani S.C., Robbins P.D., Evans C.H. \& McIlwraith C.W. 2002. Treatment of experimental equine osteoarthritis by in vivo delivery of the equine interleukin-1 receptor antagonist gene. Gene Therapy. 9(1): 12-20.

18 Gallio M., Azevedo M.S., Brass K.E., De La Corte F.D. \& Lopes L.F.D. 2014. Prevalência de alterações ósseas no tarso de potros Crioulos de até vinte e seis meses de idade. Ciência Rural. 44(8): 1442-1447.

19 Gentry L.R., Thompson D.L. \& Gentry G.T. 2004. The relationship between body condition score and ultrasonic fat measurements in mares of high versus low body condition. Journal of Equine Veterinary Science. 24(5): 198-203.

20 George L.A., Staniar W.B., Treiber K.H., Harris P.A. \& George R.J. 2009. Insulin sensitivity and glucose dynamics during pre-weaning foal development and in response to maternal diet composition. Domestic Animal Endocrinology. 37(1): 23-29.

21 Gregory J. 2012. Avaliação do desenvolvimento testicular em equinos da raça Crioula no período da peri-puberdade. 52f. Porto Alegre, RS. Dissertação (Mestrado em Medicina Animal) - Programa de Pós-Graduação em Medicina Animal - Equinos, Universidade Federal do Rio Grande do Sul.

22 Heyden V.L., Lejeune J-P., Caudron I., Detilleux J., Sandersen C., Chavatte P., Paris J., Deliège B. \& Serteyn D. 2013. Association of breeding conditions with prevalence of osteochondrosis in foals. Veterinary Record. 172(3): 68.

23 Henneke D.R., Potter G.D. \& Krieder J.L. 1983. Relationship between condition score, physical measurements and body fat percentage in mares. Equine Veterinary Journal. 15(4): 371-372.

24 Johnson R.J., Rivard C. \& Lanaspa M.A. 2013. Fructokinase, Fructans, Intestinal Permeability, and Metabolic Syndrome: An Equine Connection? Journal of Equine Veterinary Science. 33(2): 120-126.

25 Lejeune J., Franck T., Gangl M., Scheider N., Michaux C., Deby-Dupont G. \& Serteyn D. 2007. Plasma concentration of insulin-like growth factor 1 (IGF-1) in growing Ardenner horses suffering from juvenile digital degenerative osteoarthropathy. Veterinary Research Communication. 31: 185-195.

26 Long N.M., George L.A., Uthlaut A.B. Smith D.T., Nijland M.J., Nathanielsz P.W. \& Ford S.P. 2010. Maternal obesity and increased nutrient intake before and during gestation in the ewe results in altered growth, adiposity, and glucose tolerance in adult offspring. Journal Animal Science. 88(11): 3546-3553.

27 Marchiori M.O., Kasinger S., Silva K.R., Souza L.S., Amaral L.A., Nogueira C.E.W. \& Roll V.F.B. 2015. Medidas comparativas do padrão morfométrico e perfil energético de éguas Crioulas no terço final da gestação, com diferentes escores corporais. Arquivos Brasileiros de Medicina Veterinária e Zootecnia. 67(3): 707-715.

28 McIlwraith C.W. 2004. Developmental orthopedic disease: problems of limbs in young horses. Journal of Equine Veterinary Science. 24(11): 475-479.

29 Orth M.W. 1999. The regulation of growth plate cartilage turnover. Journal of Animal Science. 77(2): 183-189.

30 Ousey J.C., Fowden A.L., Wilsher S. \& Allen W.R. 2010. The effects of maternal health and body condition on the endocrine responses of neonatal foals. Equine Veterinary Journal. 40(7): 673-679.

31 Paz C.F.R., Paganela J.C., Santos C.A., Nogueira C.E.W. \& Faleiros R.R. 2013. Relação entre obesidade, insulina plasmática e posicionamento da falange distal em equinos da raça Crioula. Arquivos Brasileiros de Medicina Veterinária e Zootecnia. 65(6): 1699-1705.

32 Peugnet P., Robles M., Wimel L., Tarrade A. \& Chavatte-Palmer P. 2016. Management of the pregnant mare and long-term consequences on the offspring. Theriogenology. 86(1): 99-109. 
33 Robert C., Valette J.P. \& Denoix J.M. 2006. Correlation between routine radiographic findings and early racing career in French Trotters. Equine Veterinary Journal. 38(S36): 473-478.

34 Robles M., Nouveau E., Gautier C., Mendoza L., Dubois C. \& Dahirel M. 2018. Maternal obesity increases insulin resistance, low-grade inflammation and osteochondrosis lesions in foals and yearlings until 18 months of age. Plos One. 13(1): 1-25.

35 Santschi E.M. 2008. Articular fetlock injuries in exercising. Veterinary Clinics of North America: Equine Practice. 24(1): 117-132.

36 Satué K., Felipe M., Mota J. \& Muñoz A. 2011. Factors influencing gestational length in mares: A review. Livestock Science. 136(2): 287-294.

37 Smith S., Marr C., Dunnett C. \& Menzies-Gow N. 2017. The effect of mare obesity and endocrine function on foal birth weight in Thoroughbreds. Equine Veterinary Journal. 49(4): 461-466.

38 Van Eps A.W. \& Pollitt C.C. 2006. Equine laminitis induced with oligofructose. Equine Veterinary Journal. 38(3): 203-208.

39 Van Weeren P.R. 2006. Etiology, Diagnosis, and Treatment of OC(D). Clinical Techniques in Equine Practice. 5(4): 248-258.

40 Winter G.H.Z., Rubin M.I.B., De La Corte F.D. \& Silva C.A.M. 2007. Gestational Length and First Postpartum Ovulation of Criollo Mares on a Stud Farm in Southern Brazil. Journal of Equine Veterinary Science. 27(12): 531-534. 